\title{
A Tale of Beauties and Beasts: Testing the Optimal Disclosure Hypothesis
}

\author{
Håkan Jankensgård* \\ Lund University, Sweden
}

According to the cost-of-capital hypothesis, increased voluntary disclosure should reduce information asymmetries, lower the cost of capital, and increase firm value. The optimal-disclosure hypothesis, however, predicts that costs related to voluntary disclosure lead to the existence of an interior optimum of disclosure that maximizes firm value. These hypotheses are empirically tested using a previously unexplored database that covers disclosure rankings for listed Swedish firms between 2007 and 2012 (rendering around 1000 firm-years). The evidence is consistent with the optimal-disclosure hypothesis. I find a robust quadratic relationship between Tobin's $Q$ and the level of disclosure in annual reports. I find no significant relationship, however, between Tobin's Q and disclosure in quarterly reports or web-based reporting. (JEL: G30, G32)

Keywords: voluntary disclosure, cost of capital, Tobin's Q, optimal disclosure

\section{Introduction}

A firm that is transparent and forthcoming with information will be rewarded by capital markets with a lower required rate of return for investing its securities, thus reducing its cost of capital and increasing

* Department of Business Administration and Knut Wicksell Centre for Financial Studies, Lund University. Address: P.O. Box 7080, 22007 Lund, Sweden. Telephone: +46 46222 4285. Email: hakan.jankensgard@fek.lu.se. The author wishes to thank Hans Borneroth, Martin Isemo, Filippo Poli, Ola Bengtsson, Jens Forssbaeck, Lars Oxelheim, Gert Paulsson, Niklas Sandell, participants at the Knut Wicksell Centre for Financial Studies seminar series, and participants at the Lund Accounting Research Seminar. The author is grateful to an anonymous referee for valuable suggestions. The author gratefully acknowledges the financial support of the Jan Wallander and Tom Hedelius foundation and the Tore Browaldh foundation. Any remaining errors are the responsibility of the author alone.

(Multinational Finance Journal, 2014, vol. 18, no. 1/2, pp. 139-167)

(C) Multinational Finance Society, a nonprofit corporation. All rights reserved.

DOI: $10.17578 / 18-1 / 2-4$ 
its value. Such a view is not only the received wisdom, but it is also fairly well supported by financial theory. According to theoretical models, voluntary disclosure reduces two important sets of information asymmetries that impede financial contracting as well as trade in a firm's securities: the information gap between a firm's managers and its investors (Brown, 1979; Barry and Brown, 1984; Lambert, Leuz, and Verrecchia, 2007), and the information gap between investors with different levels of private information about the firm (Diamond and Verrecchia, 1991; Easley and O'Hara, 2004). Based on these theoretical models, subsequent empirical literature has generally assumed that the functional relationship between voluntary disclosure and the cost of capital is linear and negative (Welker, 1995; Botosan, 1997; Botosan and Plumlee, 2002; Hail, 2002). This will be referred to as the cost-of-capital hypothesis of voluntary disclosure.

The optimal disclosure-hypothesis, on the other hand, holds that voluntary disclosure increases firm value only up to a point, after which the costs of further disclosure will exceed the benefits. That is, according to this hypothesis there is a point at which the net benefit to additional disclosure turns negative. The literature has identified at least three sources of costs associated with disclosure. First, there are out-of-pocket expenses related to disclosure from having to produce and disseminate financial reports and other forms of investor communication (Singhvi and Desai, 1979). Second, disclosure may impair a firm's ability to compete in product markets since rival firms can make decisions in response to public information (e.g. Hayes and Lundholm, 1996). Third, there can be too much of a good thing: with limited abilities to absorb and process data, investors may simply 'drown' in a flood of information and have difficulties making sense of it (Oxelheim, 1999).

Several earlier papers have acknowledged the costs related to disclosure, but preferred to specify their hypothesis as indeterminate, meaning that either benefits or costs dominate (e.g. Francis, Nanda, and Olsson, 2008). However, the idea that there is an interior optimum of information release, developed further in section II of this paper, suggests that a quadratic model specification may be more appropriate. In this research I empirically investigate the cost-of-capital and optimal disclosure-hypotheses by analysing the relationship between voluntary disclosure and firm value. Firm value in this paper is measured as Tobin's Q, closely following the framework in Allayannis and Weston (2001). If the cost-of-capital hypothesis is descriptive, the relationship 
between disclosure and firm value should be positive and linear, reflecting the beneficial effect disclosure has on the cost of capital. If the optimal disclosure-hypothesis is descriptive, the squared term added to the model to capture decreasing net benefits to disclosure should be negative and significant.

This study benefits from a previously unexplored database on disclosure rankings for Swedish listed firms between 2007 and 2012. These data are unique in the sense that a comprehensive set of disclosure items have been consistently coded for a broad sample of firms over a period of six years (and running). They offer a rare chance to explore corporate disclosure with recent panel data for three important disclosure types: annual reports, quarterly reports, and web-based reporting. Since 2007 the ranking is carried out by Kanton, a Swedish financial advisory firm, in collaboration with Aktiespararna, an association representing the interests of minority shareholders in Sweden. Such rankings, or so-called 'beauty contests', are commonly used by researchers as measures of voluntary disclosure (Daske and Gebhardt, 2006). Besides the consistent coding over several years, the Swedish rankings are particularly useful for our purposes since they are based on actual disclosure items. ${ }^{1}$ For comparison, the AIMR-rankings commonly used in US studies of disclosure (e.g. Botosan and Plumlee, 2002; Jiao, 2011) stopped being produced in 1996, and were based on analysts perceptions of disclosure quality (as opposed to actual disclosure items) for specific industries. The AIMR-rankings did not separate out quarterly reports from other types of disclosure in between two annual reports (press releases, capital markets days, etc.), nor did they cover web-based disclosure specifically.

The evidence presented in this paper strongly suggests a non-linear relationship between firm value and voluntary disclosure in annual reports. Using firm-fixed effects regressions with around 1000 firm-year observations, I consistently find that the squared term is statistically significant with the negative sign predicted by the optimal disclosure-hypothesis. The results are remarkably robust. They hold across various model specifications and sub-periods. The regressions imply that, in the cross-section, firm value is optimized at levels of disclosure around $70-75 \%$ of the maximum obtainable score in any given year. The optimal disclosure hypothesis is not supported,

1. That is, firms obtain scores in the ranking to the extent they meet the pre-determined criteria. These criteria are described in detail in section III.B. 
however, when the dependent variable is any of the other two types of disclosure (disclosure in quarterly reports and web-based disclosure). The cost-of-capital hypothesis finds no support in any of the regressions. In fact, for disclosure in quarterly reports, the relationship with firm value is initially negative and significant at the 5\%-level, contradicting the hypothesis.

Rather than reflecting causality, the negative association between firm value and disclosure may of course reflect an endogenous relation (Nikolaev and Van Lent, 2005). That is, firms' asset characteristics and investment opportunities simultaneously determine optimal disclosure policies and firm value. I consider the possibility that poorly performing firms (with low Tobin's Q) are associated with higher disclosure levels because they are either under pressure from market participants to disclose more about their affairs, or because they are more reliant on external financing, which in turn pushes disclosure upwards (for evidence on the connection between disclosure and external financing, see Healy and Palepu, 2001). To explore this possibility I first add Altman's Z-score (Altman, 1968) to the model to control for the firm's financial status. While the Z-score is strongly and positively associated (at the $1 \%$-level) with both firm value and voluntary disclosure, controlling for financial status does not alter the relationship between Tobin's Q and disclosure rankings. The results continue to hold when I add various binary variables that indicate if the firm is obtaining new external financing (equity, bonds, or private debt) in a particular year. However, the result that the level of disclosure in quarterly reports is negatively related to Tobin's Q completely disappears when these variables are added, suggesting that the initial result is driven by omitted variable bias.

This paper contributes to the literature by being the first to test the optimal disclosure-hypothesis in a Tobin's Q-setting, akin to how earlier papers have sought to empirically test for a non-linear relation between managerial ownership and firm value (e.g. Morck, Shleifer, and Vishny, 1988). A few other papers in the literature have used Tobin's Q to study the value-impact of disclosure (Cheung, Jiang, and Tan, 2010; Jiao, 2011). However, none of these papers have tested for a non-linear relationship. This study fills this gap. The findings reported in this paper are in contrast with those of Cheung, Jiang, and Tan (2010), who report a strong positive relation between disclosure and Tobin's $Q$ for a sample of Chinese firms. The difference could be explained by China being a relatively low-information environment, so that information-starved 
investors put a high value on disclosures. Sweden, on the other hand, is an information-rich environment in which companies have responded to the post-Enron calls for increased transparency with substantial increases in the supply of disclosure. ${ }^{2}$

This paper also contributes to the literature on voluntary disclosure more broadly. The empirical evidence in this literature is often described as mixed, but the general presumption is that voluntary disclosure has a beneficial effect on cost of capital (and by extension firm value). Botosan $(1997,2006)$ is a good exponent of this view. Given the limitations of Tobin's Q-regressions in providing identification we need to be cautious in inferring causality, but, at a minimum, the results in this paper are inconsistent with the conjecture that disclosure has a straightforward positive effect on firm value. They are, however, consistent with a recent string of reports suggesting that Western economies are, given the exponential growth in the amount of information released in financial reports in recent decades, suffering from "information overload" (e.g. The Financial Reporting Council, 2011; European Financial Reporting Advisory Group, 2012). There is therefore reason to suspect that a significant fraction of firms overproduce information in annual reports and that, in an important sense, the winners in the so-called beauty contests may not be the real beauties after all.

The paper proceeds as follows. In Section II we review the relevant literature. Section III describes the data, variables, and methodology used in the study. Section IV contains the empirical analysis. Section V concludes the paper.

\section{Literature review}

\section{A. The cost of capital hypothesis}

As mentioned in the introduction, the basic prediction of the theoretical literature on voluntary corporate disclosure is that more disclosure generally leads to a lower cost of capital. Ceteris paribus, this implies

2. Another potential source of the difference is that these authors do not control for growth opportunities, which raises suspicions of omitted variable bias. I document in section IV.B. that capital expenditure has a strong and positive impact on all measures of voluntary disclosure. 
that firm value should increase with increased disclosure through the "denominator-effect", i.e. a lower discount rate applied to future expected cash flows. Therefore we begin with a review of this literature, followed by arguments suggesting a "nominator effect" of disclosure on firm value, i.e. lower expected future cash flows. Taken together, these two effects lead to the prediction of a disclosure level at which the net benefits from additional disclosure goes from being positive to negative.

Researchers have identified several arguments why cost of capital should be a decreasing function of the level of disclosure. One argument is that disclosure by firms decreases the information asymmetry between well-informed and less well-informed investors. Less informed investors will demand higher return to hold stocks for which private information is higher (Diamond and Verecchia, 1991; Easley and O'Hara, 2004), which increases the bid-ask spread and lowers the liquidity of the firm's shares. A policy of high disclosure will tend to mitigate this problem by making private information publicly available, thus lowering the informational advantage of informed traders.

A second line of argument focuses instead on the information asymmetry between a firm and its investors. In the process of valuing a firm's shares investors to a large extent rely on information provided by the firm itself. In asset pricing models investors are typically assumed to have perfect foresight with respect to the parameters of a security's future return distribution, which leads to the counterintuitive conclusion that corporate disclosure is irrelevant to the cost of capital. Some researchers have relaxed the perfect foresight-assumption and allowed so-called 'estimation risk' to affect a firm's cost of capital (Brown, 1979; Barry and Brown, 1984; Lambert et al., 2007). In this literature estimation risk is construed as the increase in cost of capital that arises because investors cannot be sure about the true parameters of the security's payoff distribution. Additional disclosure, then, should have a beneficial effect because it lowers the estimation risk component of the cost of capital.

A third argument for a negative relationship between disclosure and cost of capital is that increased transparency reduces agency costs. According to Leuz and Wyzocki (2008), disclosure can have first-order effects on agency problems and investment efficiency. ${ }^{3}$ The ability of

3. It should be noted that this argument relates to both the "denominator" and "nominator" effects on firm value, further supporting the use of Tobin's Q as dependent variable. By improved decision-making following more efficient monitoring, the firm would experience higher future cash flows than in the absence of such monitoring. At the same time, 
capital markets and labour markets to monitor management decreases as the level of disclosure drops, and therefore increased disclosure reduces management's possibilities for pursuing pet projects or otherwise appropriate wealth. Consequently, in order to maximize private control benefits, self-interested managers generally prefer less disclosure. This has prompted Nagar, Nanda, and Wysocki (2003) to argue that "the disclosure agency problem is the fundamental agency problem underlying other agency problems".

The empirical literature investigating the predictions of the models of voluntary disclosure originally focused on its effect on directly observable outcomes in the stock market, such as bid-ask spreads and trading volume. This strand has, by and large, been able to document the predicted negative relationship between disclosure and proxies for the firm's cost of capital (Welker, 1995; Healy, Hutton, and Palepu, 1999; Leuz and Verrecchia, 2000; Ng, 2011).

Botosan (1997) introduced a research design that aimed to measure the impact of corporate disclosure on cost of capital in a direct way. Using a discounted dividends formula, one is able to solve for the discount rate that equates the prevailing dividend forecast with the current market price. In a second step, a cross-sectional analysis of the cost of capital estimates is carried out with a disclosure index as one of the independent variables. Her main findings for the mechanics-industry in the US are that disclosure indeed is associated with a lower cost of capital, but only for firms with a low analyst following. For the full sample there is no significant relationship. Botosan and Plumlee (2002), using a larger sample, find the expected negative relationship for measures of disclosure based on annual reports, but for measures based on press-releases the opposite result is found. Using a sample of Swiss firms, Hail (2002) shows that more forthcoming firms enjoy a significantly lower cost of capital estimate, a finding attributed to a weak disclosure environment (Swiss firms having considerable latitude in setting their disclosure policy). In summary, the literature has, by and large, found the negative association that theory would predict, although the results are often described as somewhat 'mixed' (Botosan, 2006; Leuz and Wysocki, 2008).

low levels of disclosure and the suspicion of high agency costs would also serve to lower the market's trust in management, and by extension create a denominator effect on firm value through a lower cost of capital. 


\section{B. The optimal disclosure hypothesis}

While the arguments presented in the previous section suggest that there are benefits to increased disclosure, the costs of disclosure also need to be taken into account. First there are straightforward direct costs, which arise due to the need to produce and disseminate financial reports and other forms of investor communication. These activities can entail high fixed costs that are especially burdensome for small firms (Singhvi and Desai, 1979). Researchers have also identified indirect costs of disclosure. These come about mainly because information disclosed by a firm, in response to a demand for such information in the investor community, is also observed by its competitors. For example, Hayes and Lundholm (1996) develop a model in which a rival firm allocates its investment budget based on proprietary information about business segments revealed by the focal firm. Such a competitive threat is anticipated and lowers the optimal level of disclosure in equilibrium. While the above effects operate mainly on expected future cash flows, arguments have also been advanced that high levels of disclosure in fact increases cost-of-capital through an "information overload" effect. It is possible that high levels of disclosure can do more harm than good, simply because the user is overwhelmed and unable to process it with a reasonable mental effort (Oxelheim, 1999).

The existence of the above mentioned costs lead to the prediction of a quadratic relationship between disclosure and firm value. A hypothetical example will clarify. A firm that reveals no information at all is unlikely to obtain any financing whatsoever, i.e. it's cost of capital approaches infinity (and its value is correspondingly depressed). A firm that discloses an almost limitless amount of information, on the other hand, will see its value fall towards zero as the production of disclosure consumes its entire budget. The level of disclosure that optimizes firm value will lie somewhere in between.

\section{Empirical model, sample, and variables}

\section{A. Empirical model}

Most of the empirical papers in the voluntary disclosure-literature rely on the research design introduced in Botosan (1997), in which the cost of equity capital is derived as the internal rate of return that equates the 
current stock price with the forecasted dividend stream (which are obtained from security analysts). However, this empirical approach may not be suitable for tests of the optimal disclosure hypothesis. To see this, consider that the implied cost of equity-framework focuses on the denominator of the formula for firm value, i.e. the discount rate, whereas direct and proprietary costs associated with disclosure show up primarily in the nominator, i.e. they affect the level of the future expected cash flows. Tobin's Q, on the other hand, captures the impact of disclosure on both the nominator and denominator, and therefore offers a straightforward framework for testing the proposition that the costs related to disclosure "overtake" the benefits at high levels of disclosure.

The purpose of this paper is to test if firm value is influenced by voluntary disclosure, holding other factors that impact firm value constant. The general model we are interested in is as follows:

$$
\begin{gathered}
{\text { Tobins } Q_{j, t}=}_{a_{j}+d_{t}+\beta_{1} \text { Disclosure }_{j, t}+\beta_{2} \text { Disclosure }_{j, t}^{2}+} \\
\beta_{3} \text { Controls }_{j, t}+v_{j, t}
\end{gathered}
$$

where $d_{t}$ is period fixed effects, $\alpha_{j}$ is firm fixed effects, and $v_{j, t}$ is an error term. The subscript $t$ indexes time and $j$ indexes firms. Firm fixed effects are included to control for unobserved firm-level heterogeneity. Standard errors are robust to heteroskedasticity. According to the optimal disclosure-hypothesis, the coefficient $\beta_{1}$ in Eq. 1 should be positive, reflecting the benefits of reduced information asymmetries at low levels of disclosure, whereas $\beta_{2}$ should be negative, reflecting diminishing returns (and increasing costs) to incremental disclosure at higher levels of disclosure. If the cost-of-capital-hypothesis is descriptive, however, $\beta_{1}$ is still positive, but $\beta_{2}$ does not achieve significance.

\section{B. Sample}

The sample in this study consists of Swedish firms that are included in the ranking of disclosure carried out by Kanton, a Swedish financial advisory firm, and Aktiespararna, an association representing the minority shareholders in Sweden (these rankings are henceforth referred to the "KA-scores"). The KA-scores comprise firms listed on Nasdaq 
OMX and the Nordic Growth Market equity-list (NGM). NGM is a trading platform for smaller firms that seek risk capital. The ranking has been carried out every year between 2007 and 2012. ${ }^{4}$ The criteria for being included, apart from being listed on one of the two aforementioned exchanges, are that a firm is headquartered in Sweden and publishes its financial reports in Swedish. There are three separate rankings: annual reports, quarterly reports, and web-based information. According to Kanton, at least two analysts review the financial reports and web-page of each firm to ensure a consistent coding. Firms are communicated the preliminary scores they obtain, and are encouraged to review them before the final score is assigned. The criteria for each of the three categories are selected based on their perceived usefulness to financial analysts and minority shareholders. The criteria are generic in that they apply to any firm and are not industry-specific. They specifically target voluntary disclosure. When a disclosure item becomes mandatory according to IFRS ${ }^{5}$, it is subsequently removed. The criteria used are broadly consistent over time, except for a major revision in 2010. In this revision several of the easiest disclosure items were replaced by more difficult ones. Since the new criteria were harder to meet, the net effect was a drop in the average value for all three rankings in 2010.

The KA-scores cover the large majority of Swedish listed firms in any given year. The availability differs somewhat between the different disclosure-categories. In total, there are disclosure scores for firm-years as follows: yearly reports 1272; quarterly reports 1319; and web-based reporting 1338. I exclude financial firms from the sample, as they are typically considered to operate under different premises compared to non-financial firms. Financial data are obtained from Datastream. Requiring availability of financial data brings the final sample to the following number of firm-years: annual reports 1001; quarterly reports 1004; and web-based reporting 1014. The industry composition, based on the Global Industry Classification Standard (GICS) is as follows: basic materials $6 \%$; industrials $36 \%$; consumer goods $11 \%$; health care

4. Except for NGM, for which firms there was no ranking in 2011, and for the Small Cap list, for which there was no ranking in 2011 or 2012. The Small Cap list, which together with the Mid Cap and Large Cap lists makes up the Nasdaq OMX, covers firms with a market cap below $€ 150$ million.

5. IFRS refers to International Financial Reporting Standards, which is the accounting standard followed by public firms in Sweden since 2005. 
$13 \%$; consumer services $13 \%$; telecommunications $2 \%$; technology $16 \%$; oil \& gas $3 \%$; and utilities $0 \%$.

\section{Measuring disclosure}

I define four disclosure scores: DISCY, DISCQ, DISCW and DISCT. DISCY is the number of points the firm obtains in the Kanton/Aktiespararna disclosure ranking for annual reports, divided by the maximum obtainable score in that year. ${ }^{6}$ For example, if the maximum number of coded disclosure items for annual reports is 42 , and the firm discloses 28 of them, DISCY is $28 / 42=67 \%$. DISCQ and DISCW are the corresponding scores for disclosure in quarterly reports and on the web, respectively. DISCT is the sum of DISCY, DISCQ, and DISCW and serves as a measure of total disclosure.

To give an idea of what the KA-scores are based on, consider first the ranking of disclosure in annual reports. In 2011, this ranking was based on 42 disclosure items, which thus was the maximum obtainable score. The subcategories were: 1) important events during the year in table/list format (1 item), 2) description of the company by senior decision-makers (6 items), 3) description of the company's strategies, financial targets, markets, competition and sustainability work (17 items) 4) financial overview (i.e. key ratios and performance indicators five years back in time, (4 items), 5) corporate governance (3 items), 6) dividend policy (1 item), 7) forecasts (2 items), 8) risk analysis (5 items), 9) dictionary covering important terms (2 items), 10) statement concerning the policy for distributing financial reports (1 item).

In 2011, the 19 criteria for quarterly reports were: 1) important events during the quarter (1 item), 2) statement from the CEO (3 items), 3 ) financial ratios (3 items). 4) performance overview at least eight quarters back (3 items), 5) seasonal effects (1 item), 6) market developments (1 item), 7) brief description of the firm (4 items), 8) other (3 items). In the same year, the 35 criteria for web-based reporting were as follows: 1) basic functions, e.g. search (2 items), 2) non-financial information, e.g. organization map (14 items), 3) financial information in excel-format (4 items), 4) web broadcasts (1 item), 5) calendar of events (2 item), 6) risk analysis (5 items), 7) contact

6. The disclosure score is normalized with the maximum score to account for the fact that the maximum obtainable value differs between the years, as well as to make it possible to sum the three measures in the ranking into a measure of total disclosure. In the robustness section I investigate results without this normalization. Results are qualitatively unchanged. 
information (2 items), 8) information about the share and ownership (3 items), 9) dictionary (2 items). The complete set of definitions, criteria, and rankings for all years are available from the author on request.

As noted in the introduction, the KA-scores have important advantages over the US-based AIMR-rankings ${ }^{7}$ used in several previous studies on voluntary disclosure (e.g. Botosan and Plumlee, 2002; Jiao, 2011). Whereas the latter are based on analysts' perceptions of disclosure quality, the KA-scores reflect firms' ability to meet pre-defined criteria for actual disclosure items. They are also recent (the AIMR-scores stopped being produced in 1996). Furthermore, the AIMR-scores are only available for large firms with significant analyst followings, limiting the generalizability of results based on them (Jiao, 2011). The KA-scores, on the other hand, cover a broad cross-section of firms and include the great majority of all listed firms in Sweden.

Other researchers have constructed their own disclosure indexes and manually coded firm's financial reports (e.g. Botosan, 1997). These tend to be limited to a small number of years and industries. ${ }^{8}$ Kanton/Aktiespararna has consistently coded a broad cross-section of firms for six years running with largely consistent disclosure criteria (except for the revision in 2010, as discussed earlier).

\section{Measuring firm value}

To estimate firm value I define TOBINSQ as total book value of assets minus book value of equity plus market value of assets, divided by total book value of assets (Datastream codes: (WC02999-WC03501+ WC08001)/WC02999). Since TOBINSQ exhibits a skewed distribution I follow the practice in the literature of taking the natural log, which also has the advantage of allowing interpretations of regression coefficients in percentage terms. To reduce outlier concerns, TOBINSQ is winsorized at the $1^{\text {st }}$ and $99^{\text {th }}$ percentiles.

\section{E. Other determinants of firm value}

The control variables used in this study draw on Allayannis and Weston (2001). The variables are as follows (Datastream code in parenthesis).

7. AIMR is an abbreviation of Association for Investment and Management Research.

8. Botosan (1997), for example, bases her results on a single year and a single industry (manufacturing). 
TABLE 1. Summary of variables used in this study

\begin{tabular}{|c|c|c|c|}
\hline & Description & Calculation & Data source \\
\hline DISCY & $\begin{array}{l}\text { The score obtained in } \\
\text { Kanton-Aktiespararnas } \\
\text { yearly analysis of } \\
\text { disclosure provided in } \\
\text { annual reports }\end{array}$ & $\begin{array}{l}\text { Score in a given } \\
\text { year/Maximum } \\
\text { obtainable score in that } \\
\text { year }\end{array}$ & $\begin{array}{l}\text { Kanton and } \\
\text { Aktiespararna }\end{array}$ \\
\hline DISCQ & $\begin{array}{l}\text { The score obtained in } \\
\text { Kanton-Aktiespararnas } \\
\text { yearly analysis of } \\
\text { disclosure provided in } \\
\text { quarterly reports }\end{array}$ & $\begin{array}{l}\text { Score in a given year } \\
\text { /Maximum obtainable } \\
\text { score in that year }\end{array}$ & $\begin{array}{l}\text { Kanton and } \\
\text { Aktiespararna }\end{array}$ \\
\hline DISCW & $\begin{array}{l}\text { The score obtained in } \\
\text { Kanton-Aktiespararnas } \\
\text { yearly analysis of } \\
\text { disclosure provided on } \\
\text { the firm's webpage }\end{array}$ & $\begin{array}{l}\text { Score in a given year } \\
\text { /Maximum obtainable } \\
\text { score in that year }\end{array}$ & $\begin{array}{l}\text { Kanton and } \\
\text { Aktiespararna }\end{array}$ \\
\hline TOBINSQ & $\begin{array}{l}\text { The log of: (Total } \\
\text { assets minus book } \\
\text { value of equity plus the } \\
\text { market value of } \\
\text { equity)/Total assets }\end{array}$ & $\begin{array}{l}\log ((\mathrm{WC} 02999- \\
\text { WC03501+ WC08001) } \\
\text { /WC02999) }\end{array}$ & Datastream \\
\hline SIZE & Log of total assets & Log(WC02999) & Datastream \\
\hline PROFITABILITY & Net income/Total assets & WC01706/WC02999 & Datastream \\
\hline LEVERAGE & Total debt/Total assets & WC03255/WC02999 & Datastream \\
\hline CAPEX & $\begin{array}{l}\text { Investment in fixed } \\
\text { assets/Total assets }\end{array}$ & WC04601/WC02999 & Datastream \\
\hline GEOGRAPHICAL & $\begin{array}{l}\text { Number of } \\
\text { geographical segments } \\
\text { for which revenue is }>0\end{array}$ & $\begin{array}{l}\text { WC19601 through } \\
\text { WC19681 }\end{array}$ & Datastream \\
\hline DIVERSIFICATION & $\begin{array}{l}\text { Number of product } \\
\text { segments for which } \\
\text { revenue is }>0\end{array}$ & $\begin{array}{l}\text { WC19501 through } \\
\text { WC19581 }\end{array}$ & Datastream \\
\hline
\end{tabular}

SIZE is defined as the log of total assets (WC02999). PROFITABILITY is defined as net income divided by total assets (WC01706/WC02999). LEVERAGE is defined as total debt divided by total assets (WC03255/WC02999). CAPEX is defined as investments in fixed assets divided by total assets (WC04601/WC02999). GEOGRAPHICAL is the number of geographical segments for which the firm reports revenue (WC19600). DIVERSIFICATION is the number of product segments for which the firm reports revenue (WC19500). To reduce 
outlier concerns, the variables PROFITABILITY, LEVERAGE and CAPEX are winsorized at the $1^{\text {st }}$ and $99^{\text {th }}$ percentiles.

The variables used in the study are summed up in table 1.

\section{Results}

\section{A. Descriptive statistics}

Table 2 reports the descriptive statistics of the variables introduced in section III. Interestingly, for DISCQ and DISCW there are firm-years in which one or more firms fail to obtain even a single point. Generally, there is significant variation in the disclosure scores. ${ }^{9}$ To illustrate the relationship between firm value and disclosure without any controls, table 3 shows the average TOBINSQ associated with different deciles of DISCY.

Correlation coefficients are not tabulated (although available from the author). Pearson correlations between all three disclosure indexes are positive and statistically significant. DISCY has the highest correlation with DISCQ (0.57), and the lowest correlation is between DISCQ and DISCW (0.31). Size correlates positively with both DISCY (0.28) and DISCW (0.45), but, surprisingly, the correlation with DISCQ is negative and insignificant. Large firm thus appear to disclose relatively less in their quarterly reports. Most other control variables are generally positively and significantly related to DISCY, but this may be attributable to the size-effect, and thus we need a ceteris paribus setting to gauge marginal effects. This is provided in the following section.

\section{B. Determinants of disclosure}

In this section we analyze the determinants of our disclosure indexes in a multivariate setting using the empirical model outlined in section III.E. Table 4 reports the results.

In table 4 we see that two variables are statistically significant in explaining the disclosure rankings across the four measures: SIZE and CAPEX. As expected, SIZE positively influences the amount of disclosure, consistent with previous research (Marston and Shrives,

9. Note that table 2 reports the untransformed values of the disclosure scores, not the normalized ones used in later regressions. 
TABLE 2. Descriptive statistics

\begin{tabular}{lrrrrr}
\hline & Mean & Median & Min & Max & $\begin{array}{c}\text { Standard } \\
\text { deviation }\end{array}$ \\
\hline DISCY & 26.780 & 27.500 & 5.000 & 46.000 & 8.471 \\
DISCQ & 9.638 & 9.000 & 0.000 & 21.000 & 4.265 \\
DISCW & 9.858 & 9.500 & 0.000 & 31.500 & 5.994 \\
TOBINSQ & 1.958 & 1.444 & 0.539 & 12.130 & 1.709 \\
SIZE & 14.307 & 14.100 & 8.923 & 19.705 & 2.165 \\
PROFIT & 0.004 & 0.048 & -1.197 & 0.383 & 0.203 \\
LEVERAGE & 0.187 & 0.157 & 0.000 & 0.704 & 0.163 \\
CAPEX & 0.037 & 0.022 & 0.000 & 0.411 & 0.051 \\
GEOGRAPHICAL & 3.297 & 3.000 & 0.000 & 10.000 & 2.983 \\
DIVERSIFICATION & 2.807 & 3.000 & 0.000 & 10.000 & 1.800 \\
\hline
\end{tabular}

Note: This table provides the mean, median, minimum, maximum and standard deviation of the variables used in this study (based on a common sample, 991 firm-year observations). NOTE: the untransformed values for the disclosure rankings (DISCY, DISCQ, and DISCW) are shown. In later regressions these variables are normalized using the maximum obtainable score in any given year.

1991). The positive coefficient on CAPEX indicates that faster-growing firms are more prone to disclose information. Possibly this reflects the perceived need of these companies to finance their growth in the capital markets and thus release more information. These results imply that future research should incorporate this variable in models of firms' disclosure (for example, neither Lang and Lundholm, 1993, nor Nagar et al., 2003, include investment growth indicators in their regressions). Somewhat surprisingly, the coefficient on PROFITABILITY has a positive sign only for the disclosure ranking based on quarterly reports. DIVERSIFIED is positively related to total disclosure (DISCT), consistent with the notion that these firms are more complex, and thus require more disclosure to counteract information asymmetries.

\section{Testing the cost-of-capital hypothesis}

In this section we report the results from a multivariate analysis in which the dependent variable is TOBINSQ. The goal is to test the relationship between firm value and firms' disclosure policy without a squared term. According to the cost-of-capital hypothesis there exists a positive relationship between these variables reflecting the beneficial impact of disclosure on the cost of capital. To test this proposition, we 
TABLE 3. Median Tobin's $Q$ at different deciles of DISCY

\begin{tabular}{cc}
\hline Percentile of DISCY & Median value Tobin's Q \\
\hline $0-10$ & 1.504 \\
$10-20$ & 1.694 \\
$20-30$ & 1.508 \\
$30-40$ & 1.431 \\
$40-50$ & 1.432 \\
$50-60$ & 1.328 \\
$60-70$ & 1.398 \\
$70-80$ & 1.221 \\
$80-90$ & 1.264 \\
$90-100$ & 1.184 \\
\hline
\end{tabular}

Note: This table reports the median Tobin's Q for different deciles of the disclosure index DISCY, which is based on a ranking of the level of disclosure in annual reports carried out by Kanton and Aktiespararna. Kanton is a Swedish financial advisory firm. Aktiespararna is an association representing small shareholders in Sweden. The data cover the period 2007-2012. There are roughly 100 observations for each decile.

carry out four regressions with TOBINSQ as dependent. Models 1-3 have the same set of independent variables except that the Model 1 includes DISCY; Model 2 includes DISCQ; and Model 3 includes DISCW. While correlations between the three rankings are not overwhelmingly high, the results for all three are reported one by one in order to alleviate concerns about multicollinearity. Model 4 includes all three rankings. Table 5 reports the results from these regressions.

In Table 5 we see that the data generally does not support the cost-of-capital hypothesis. Neither DISCY nor DISCW achieve significance at conventional levels. The only significant disclosure-variable is DISCQ (at the 5\%-level), but the negative sign is contrary to expectations. Of the control variables, CAPEX is highly significant with the expected sign. Consistent with most prior studies, SIZE is negatively related to firm value.

\section{Testing the optimal disclosure-hypothesis}

In this section we proceed to test the optimal disclosure-hypothesis. Compared to the regressions in section IV.C the only difference is that we add the squared term of each of the disclosure scores. Models 1-3 in table 6 therefore reports results from regressions containing each of the three disclosure rankings together with a squared term. If the optimal 
TABLE 4. An OLS-model of disclosure levels

\begin{tabular}{lcccc}
\hline Variables & Model 1 & Model 2 & Model 3 & Model 4 \\
& DISCY & DISCQ & DISCW & DISCT \\
\hline $\mathrm{C}$ & -0.030 & -0.032 & $0.314^{* * *}$ & $-0.301^{* * *}$ \\
& $(-0.29)$ & $(-0.71)$ & $(6.49)$ & $(-5.79)$ \\
SIZE & $0.071^{* * *}$ & $0.030^{* * *}$ & $0.008^{* * *}$ & $0.031^{* * *}$ \\
& $(10.83)$ & $(10.74)$ & $(2.89)$ & $(9.77)$ \\
PROFITABILITY & 0.075 & $0.045^{* *}$ & 0.022 & 0.005 \\
& $(1.54)$ & $(2.15)$ & $(1.03)$ & $(0.23)$ \\
LEVERAGE & 0.000 & -0.001 & -0.017 & 0.017 \\
& $(0.01)$ & $(-0.05)$ & $(-0.60)$ & $(0.57)$ \\
CAPEX & $0.622^{* * *}$ & $0.150^{*}$ & $0.216^{* *}$ & $0.274^{* * *}$ \\
& $(3.07)$ & $(1.70)$ & $(2.35)$ & $(2.79)$ \\
GEOGRAPHICAL & 0.000 & -0.000 & 0.001 & 0.000 \\
& $(0.09)$ & $(-0.49)$ & $(0.84)$ & $(0.04)$ \\
DIVERSIFICATION & 0.009 & 0.001 & -0.002 & $0.009^{* * *}$ \\
& $(1.55)$ & $(0.60)$ & $(-0.78)$ & $(3.30)$ \\
\hline Adj R-Sqr & 0.398 & 0.306 & 0.372 & 0.297 \\
Firm-years & 1001 & 1004 & 1014 & 1016 \\
Firm fixed effects & No & No & No & No \\
Industry fixed effects & Yes & Yes & Yes & Yes \\
Year fixed effects & Yes & Yes & Yes & Yes \\
& & & &
\end{tabular}

Note: This table shows the results from an OLS estimation of the determinants of disclosure levels for Swedish listed firms between 2007 and 2012. Models 1-4 differ only in terms of dependent variable. In Model 1 the dependent is the ranking of the disclosure level in annual reports (DISCY). In Model 2 the dependent is the ranking of the disclosure level in quarterly reports (DISCQ). In Model 3 the dependent is the ranking of the disclosure level on corporate webpages (DISCW). In Model 4 the dependent is the sum of the three aforementioned rankings (DISCT). T-statistics based on robust standard errors are reported in parenthesis. Superscripts ***, $* *$, and $*$ indicate significance at the $1 \%, 5 \%$, and $10 \%$ levels, respectively.

disclosure hypothesis is descriptive the squared term should be negative and significant. In Model 4 we include the yearly ranking, DISCY, together with its squared term, as well as DISCQ and DISCW as controls.

In table 6 we can see that the only squared term that is significant is DISCY^$^{\wedge} 2$. Thus, the optimal disclosure-hypothesis appears to find some support, but only for the disclosure related to annual reports. We will come back to the interpretation of this finding in section III.G. Before this, however, we will investigate how robust the finding with respect to DISCY is (section IV.E) and the possibility that the result reflects not 
TABLE 5. An OLS-model of firm value: Testing the cost-of-capital hypothesis

\begin{tabular}{lcccc}
\hline Variables & Model 1 & Model 2 & Model 3 & Model 4 \\
\hline C & $3.305^{* *}$ & $3.277^{* *}$ & $3.256^{* *}$ & $3.360^{* *}$ \\
& $(2.07)$ & $(2.08)$ & $(2.11)$ & $(2.12)$ \\
DISCY & 0.204 & & & 0.259 \\
DISCQ & & & & $-0.124^{*}$ \\
& & $-0.108^{* *}$ & & \\
DISCW & & & & -0.149 \\
SIZE & & & -0.146 & \\
& $-0.205^{*}$ & $-0.192^{*}$ & $-0.191^{*}$ & $-0.204^{*}$ \\
PROFITABILITY & $(-1.96)$ & $(-1.76)$ & $(-1.80)$ & $(-1.94)$ \\
& -0.024 & -0.029 & -0.033 & -0.038 \\
LEVERAGE & $(-0.16)$ & $(-0.18)$ & $(-0.21)$ & $(-0.25)$ \\
& -0.096 & -0.113 & -0.123 & -0.099 \\
CAPEX & $(-1.05)$ & $(-1.19)$ & $(-1.41)$ & $(-0.99)$ \\
& $0.796^{* * *}$ & $0.806^{* * *}$ & $0.811^{* * *}$ & $0.796^{* * *}$ \\
GEOGRAPHICAL & $(3.43)$ & $(3.49)$ & $(3.43)$ & $(3.49)$ \\
& -0.001 & -0.000 & -0.000 & -0.000 \\
DIVERSIFICATION & $(-0.16)$ & $(-0.04)$ & $(-0.01)$ & $(-0.09)$ \\
& -0.006 & -0.008 & -0.007 & -0.006 \\
\hline Adj R-Sqr & $(-0.75)$ & $(-0.88)$ & $(-0.82)$ & $(-0.74)$ \\
Firm-years & 0.868 & 0.868 & 0.869 & 0.869 \\
Firm fixed effects & 994 & 1004 & 1006 & 991 \\
Industry fixed effects & Yes & Yes & Yes & Yes \\
Year fixed effects & No & No & No & No \\
\hline
\end{tabular}

Note: This table shows the results from an OLS estimation of the determinants of firm value (Tobin's Q) for Swedish listed firms between 2007 and 2012. Models 1-3 differ only in which of the disclosure rankings that are included as independent variable. Model 1 includes the ranking of the disclosure level in annual reports (DISCY) as independent. Model 2 includes the ranking of the disclosure level in quarterly reports (DISCQ) as independent. Model 3 includes the ranking of the disclosure level on corporate webpages (DISCW) as independent. Model 4 includes all three disclosure rankings. T-statistics based on robust standard errors are reported in parenthesis. Superscripts $* * *, * *$, and * indicate significance at the $1 \%, 5 \%$, and $10 \%$ levels, respectively.

causality but an endogenous relation (section IV.F).

\section{E. Robustness}

In this section I report a number of robustness checks of the findings in the previous section, namely that the optimal disclosure-hypothesis appears to be descriptive for the relationship between disclosure 
TABLE 6. An OLS-model of firm value: Testing the optimal disclosure hypothesis

\begin{tabular}{|c|c|c|c|c|}
\hline Variables & Model 1 & Model 2 & Model 3 & Model 4 \\
\hline $\mathrm{C}$ & $\begin{array}{l}3.076^{*} \\
(1.87)\end{array}$ & $\begin{array}{l}3.238^{* *} \\
(2.06)\end{array}$ & $\begin{array}{l}3.261^{* *} \\
(2.10)\end{array}$ & $\begin{array}{l}3.131 * \\
(1.92)\end{array}$ \\
\hline DISCY & $\begin{array}{l}1.852^{*} \\
(1.95)\end{array}$ & & & $\begin{array}{c}1.885^{*} \\
(1.96)\end{array}$ \\
\hline $\operatorname{DISCY}^{\wedge} 2$ & $\begin{array}{l}-1.567^{* *} \\
(-1.97)\end{array}$ & & & $\begin{array}{l}-1.547^{*} \\
(-1.95)\end{array}$ \\
\hline DISCQ & & $\begin{array}{r}0.197 \\
(0.82)\end{array}$ & & $\begin{array}{c}-0.118^{*} \\
(-1.665)\end{array}$ \\
\hline $\mathrm{DISCQ}^{\wedge} 2$ & & $\begin{array}{c}-0.318 \\
(-1.51)\end{array}$ & & \\
\hline DISCW & & & $\begin{array}{l}-0.296 \\
(-0.72)\end{array}$ & $\begin{array}{l}-0.146 \\
(-1.21)\end{array}$ \\
\hline $\mathrm{DISCW}^{\wedge} 2$ & & & $\begin{array}{c}0.212 \\
(0.38)\end{array}$ & \\
\hline SIZE & $\begin{array}{l}-0.218^{* *} \\
(-2.29)\end{array}$ & $\begin{array}{l}-0.194 * \\
(-1.77)\end{array}$ & $\begin{array}{l}-0.190 * \\
(-1.79)\end{array}$ & $\begin{array}{l}-0.217^{* *} \\
(-2.27)\end{array}$ \\
\hline PROFITABILITY & $\begin{array}{l}-0.019 \\
(-0.14)\end{array}$ & $\begin{array}{c}-0.026 \\
(-0.17)\end{array}$ & $\begin{array}{l}-0.037 \\
(-0.23)\end{array}$ & $\begin{array}{l}-0.032 \\
(-0.23)\end{array}$ \\
\hline LEVERAGE & $\begin{array}{l}-0.078 \\
(-0.89)\end{array}$ & $\begin{array}{l}-0.117 \\
(-1.23)\end{array}$ & $\begin{array}{l}-0.119 \\
(-1.43)\end{array}$ & $\begin{array}{l}-0.081 \\
(-0.87)\end{array}$ \\
\hline CAPEX & $\begin{array}{l}0.884^{* * *} \\
(3.11)\end{array}$ & $\begin{array}{l}0.798^{* * *} \\
(3.41)\end{array}$ & $\begin{array}{l}0.812^{* * *} \\
(3.44)\end{array}$ & $\begin{array}{l}0.882^{* * *} \\
(3.18)\end{array}$ \\
\hline GEOGRAPHICAL & $\begin{array}{l}-0.001 \\
(-0.19)\end{array}$ & $\begin{array}{l}-0.000 \\
(-0.03)\end{array}$ & $\begin{array}{l}-0.000 \\
(-0.02)\end{array}$ & $\begin{array}{l}-0.000 \\
(-0.12)\end{array}$ \\
\hline DIVERSIFICATION & $\begin{array}{c}-0.004 \\
(-0.53)\end{array}$ & $\begin{array}{l}-0.009 \\
(-0.92)\end{array}$ & $\begin{array}{l}-0.007 \\
(-0.74)\end{array}$ & $\begin{array}{c}-0.004 \\
(-0.51)\end{array}$ \\
\hline Adj R-Sqr & 0.823 & 0.821 & 0.821 & 0.824 \\
\hline Firm-years & 994 & 1004 & 1006 & 991 \\
\hline Firm fixed effects & Yes & Yes & Yes & Yes \\
\hline Industry fixed effects & No & No & No & No \\
\hline Year fixed effects & Yes & Yes & Yes & Yes \\
\hline
\end{tabular}

Note: This table shows the results from an OLS estimation of the determinants of firm value (Tobin's Q) for Swedish listed firms between 2007 and 2012. The difference compared to table 5 is that the models presented in this table contain a squared term to allow for diminishing net benefits to incremental disclosure. Models 1-3 differ only in which of the disclosure rankings that are included as dependent variable. Model 1 includes the ranking of the disclosure level in annual reports (DISCY), and its squared term, as independents. Model 2 includes the ranking of the disclosure level in quarterly reports (DISCQ), and its squared term, as independents. Model 3 includes the ranking of the disclosure level on corporate webpages (DISCW), and its squared term, as independents. Model 4 includes all three disclosure rankings and but only the squared term for DISCY. T-statistics based on robust standard errors are reported in parenthesis. Superscripts $* * *, * *$, and $*$ indicate significance at the $1 \%, 5 \%$, and $10 \%$ levels, respectively. 


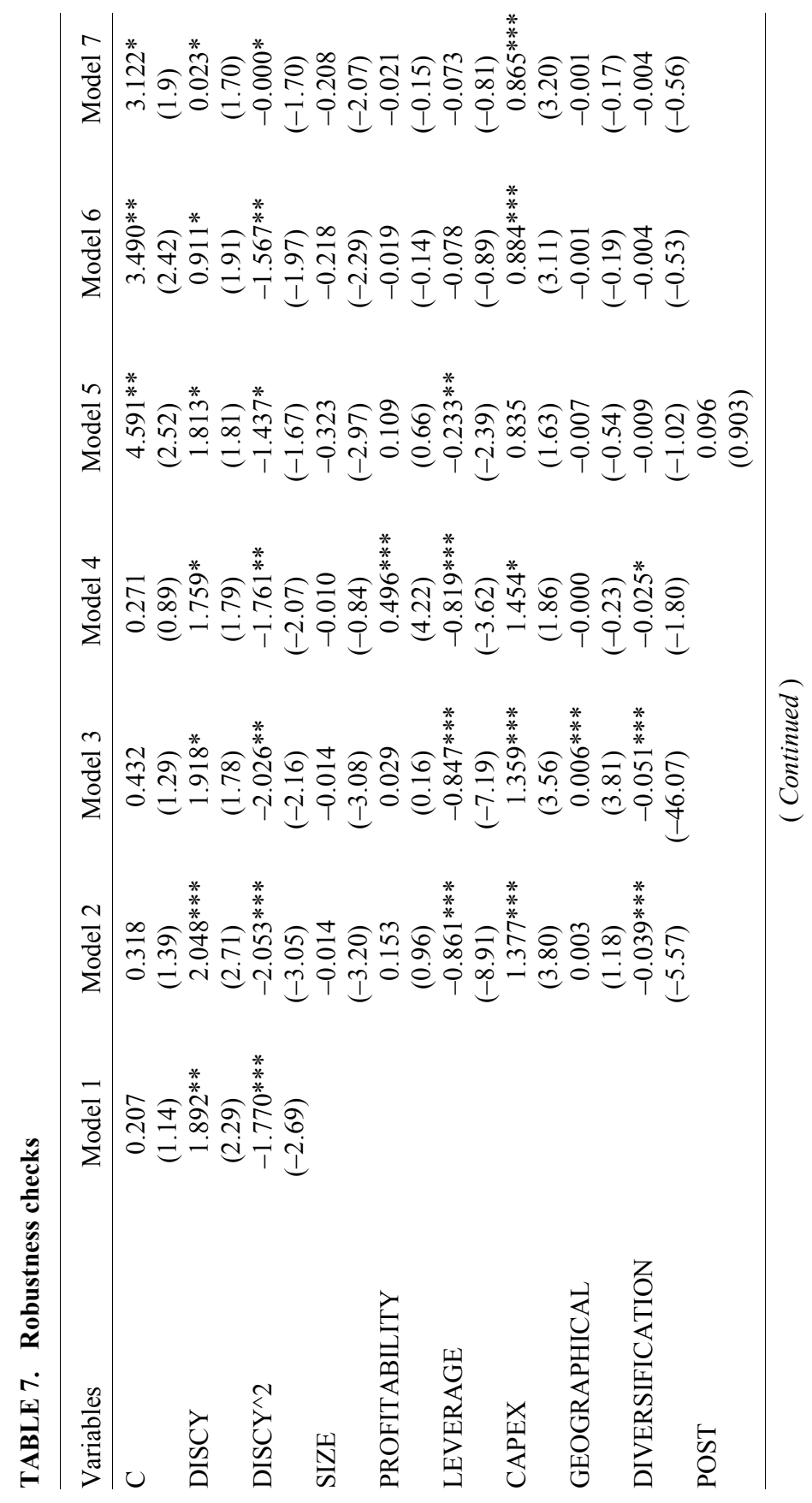




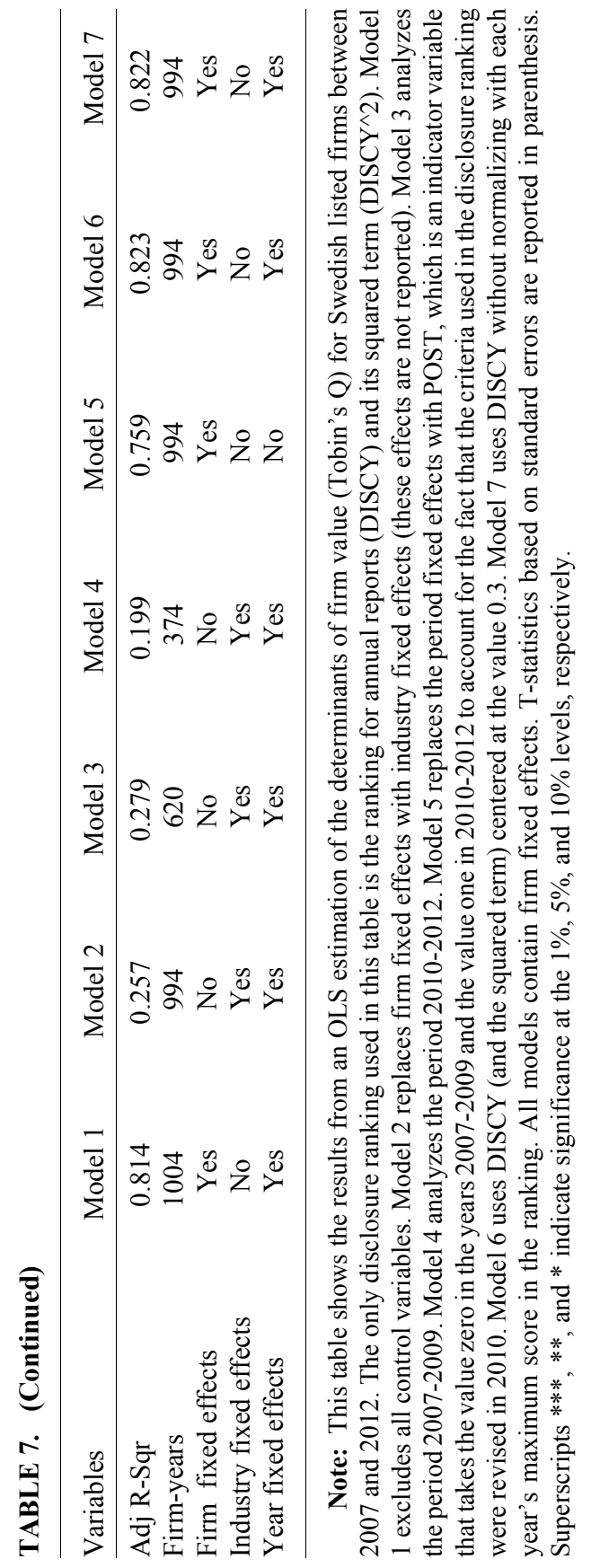


rankings for annual reports (DISCY) and firm value (measured as TOBINSQ). These robustness tests are reported in table 7.

We begin by considering a model that excludes all controls (Model 1). The squared term is still significant, but the coefficient on DISCY is now marginally insignificant ( $\mathrm{p}$-value $=0.12$ ).

Next we replace firm fixed effects with industry fixed effects. Now both DISCY and DISCY^ 2 are highly significant. Many of the control variables show higher significance as well. LEVERAGE is now (negatively) significant at the $1 \%$-level. DIVERSIFICATION is also negative and significant at the $1 \%$-level, suggesting that the market places a discount on diversified firms. Possibly the improved significance on DIVERSIFICATION reflects a rather low variability over time in this variable, so that it adds little information to the model when firm fixed effects are included.

In Models 3 and 4 we decompose the sample into two sub-periods: 2007-2009 and 2010-2012. In the first period the financial crisis was in its most intense phase, and the market may value disclosure higher in such an environment compared to the, relatively speaking, more stable later period (also, as discussed further below, in 2010 the criteria in the KA-ranking were revised). However, we find that DISCY and DISCY^2 achieve statistical significance at similar levels in both periods. ${ }^{10}$

In Model 5 we replace the year-fixed effects with a binary variable labelled POST that takes the value 1 in the years 2010 to 2012, zero otherwise. This is done to account for the fact that the criteria used in the KA-rankings were revised in this year, leading to a downward shift after 2009. However, the main results are unaffected by including POST, suggesting that the revision of the criteria in 2010 are not impacting these results to a meaningful degree.

In Model 6 DISCY has been centered at 0.3. Centering is a common technique for dealing with multicollinearity between two variables in a regression, such as interaction terms or polynomials. Model 6 suggests that the results are largely unaffected by centering.

In Model 7 DISCY is not normalized using the maximum obtainable score in a given year as in previous regressions. That is, we use the actual, untransformed score obtained in the ranking. Again, we find that the main results continue to hold.

10. The sub-period 2010-2012 has fewer observations because there were no rankings for firms listed on the NGM stock exchange in 2011 and no ranking for firms on the Small Cap list in 2011 and 2012. 
In summary, the results presented in this section show that the findings with regard to the relationship between firm value and disclosure in annual reports is robust to a large number of model specifications, variable definitions, and different sub-periods.

\section{F. Endogeneity}

When interpreting these results, it should be kept in mind that disclosure and firm value are naturally endogenous variables (Nikolaev and Van Lent, 2005). For example, talented managers may use voluntary disclosure as a way to signal their ability (Healy and Palepu, 2001). It could therefore be expected that high-performing firms are more forthcoming with information, which could induce a spurious relation between firm value and voluntary disclosure. Apart from including firm fixed effects in the regressions, I have also controlled for profitability in all models in order to mitigate concerns about this type of self-selection, which previous research has shown to be positively related to disclosure (Lang and Lundholm, 1993). It should furthermore be noted that the self-selection bias predicts a positive relationship between firm value and disclosure. The documented negative association is not consistent with the self-selection bias.

A more serious concern is that the association between Tobin's Q and disclosure arises because low-Q firms score highly on the disclosure rankings because they are under more intense scrutiny from investors and analysts. That is, due to their fledgling performance, these firms may be pressured to "come clean" by increasing disclosure levels. That is, the demand for disclosure could possibly be a decreasing function of the firm's financial status. To control for this possibility I include Altman's Z-score (Altman, 1968) in the model. ${ }^{11}$ The Z-score is a composite measure of various financial indicators and is typically used to predict the likelihood of default, or as a general measure of the firm's financial status. In untabulated regressions I find that including the Z-score does not alter any of the conclusions. In fact, the coefficients on DISCY and DISCY^ 2 achieve somewhat higher statistical significance. The Z-score itself is, as expected, positive and significant at the $1 \%$-level. I also rerun the regressions in table 4 including the Z-score,

11. Actually, I include a variable labelled ZDISCRETE, which sorts the Z-score into quartiles. This is done because the Z-score, due to its reliance on financial ratios, is an inherently noisy variable that substantially violates the normality-assumption. 
finding a positive and highly significant relationship, suggesting that voluntary disclosure is an increasing function of the firm's financial status. It is possible that the Z-score captures the aforementioned self-selection bias better than the profitability-measure. It may also be that financially healthy firms simply have more resources to devote to disclosure-related activities.

Financially weaker (low Q) firms may be more prone to obtain more new external financing, which could drive disclosure activities (see Healy and Palepu, 2001). This could indirectly cause an association between firm value and disclosure. To control for this possibility I create three binary variables that indicate if a firm obtains new financing in a given year (equity issue, bond issue, and private debt-issue). ${ }^{12}$ Including the financing-variables, in addition to the Z-score, does not change the main results with respect to DISCY and DISCY^2.

The other main finding so far is that the disclosure score for quarterly reports is negatively associated with Tobin's Q. Here we may again conjecture that the relationship is caused by financially weak (low Q) firms being pressured to disclose more information. This may be particularly relevant for quarterly reports since investors may be keen to keep track of developments at more frequent intervals for struggling firms compared to well-performing ones. In contrast to DISCY, the result on DISCQ disappears when the Z-score is included in the model $(p$-value $=0.18)$. This supports the conjecture that the demand for information is a negative function of the firm's financial status, and that the original finding on DISCQ is driven by omitted variable bias. Including the financing-event dummies the significance on DISCQ drops even further $(\mathrm{p}$-value $=0.38)$.

\section{G. Discussion}

One of the advantages of the KA-scores employed in this paper as measures of voluntary disclosure is that they target three different types of disclosure: yearly reports, quarterly reports, and web-based reporting.

12. EQUITY takes the value 1 if the firm, according to its annual report, issues new equity (source: Datastream). BOND takes the value 1 if the firm issues a bond (source: CapitalIQ). PRIVATEDEBT takes the value 1 if the firm issues debt in excess of the amount obtained from bond issues. It is computed by first taking the borrowing in the cash flow statement and subtracting the proceeds from bond issues, and then setting it to 1 if this amount is above zero (source: Datastream and CapitalIQ). 
The results indicate that, when the omitted variable bias is addressed, neither disclosure in quarterly nor web-based reporting has an effect on firm value. For yearly reports we find that the relationship between disclosure and firm value is positive at low levels of disclosure but that, at higher levels of disclosure, additional disclosure is associated with decreases in value. By inserting potential values of DISCY into the model (Model 7 in table 7) one finds that firm value is optimized at disclosure scores that correspond to $70-75 \%$ of the maximum obtainable value.

How reasonable is it that the evidence is consistent with the optimal disclosure-hypothesis only for disclosure in annual reports? According to a string of recent reports, the number of data points in annual reports has grown exponentially in Western economies and investors are consequently plagued by “information overload". For example, a report by the Financial Reporting Council (UK) from 2011 entitled 'Cutting Clutter: Combating the Clutter in Annual Reports' argues that, by obscuring relevant information, too much disclosure makes it more difficult for investors and analysts to assess a firm's progress. In a similar vein, the European Financial Reporting Advisory Group (EFRAG) released a discussion paper in 2012, arguing that the surge of information in financial reports has become 'a burden' for investors, who 'fail to see the wood for the trees'.

Put differently, these reports argue that disclosure increases the amount of information available but may actually decrease transparency as perceived by investors. In principle, a firm's cost of capital should be a decreasing function of the perceived transparency of the firm, not the availability of information per se. At least in Sweden, this problem of 'clutter' seems to be related primarily to annual reports. Whereas quarterly reports tend to be wafer-thin, annual reports are often massive documents. ${ }^{13}$ To illustrate the growth in disclosure figure 1, courtesy of EFRAG, shows the development number of data points in the annual reports of Roche Ltd. from the early 1970 s until $2008 .{ }^{14}$

In a cross-section, the finding that the squared term is negative and

13. For example, in 2009 software firm Ericsson's annual report had 172 pages.

14. Note that Roche, a global biotech firm, is not included in the sample used in this study, and that the time period in figure 1 only partially overlaps the sample period of my data. I have been unable to find a corresponding graph for any of the firms included in the sample. In all likelihood, Swedish listed firms display a similar pattern over time. The author is grateful to Filippo Poli at EFRAG for making the graph available. 


\section{Roche External Reporting}

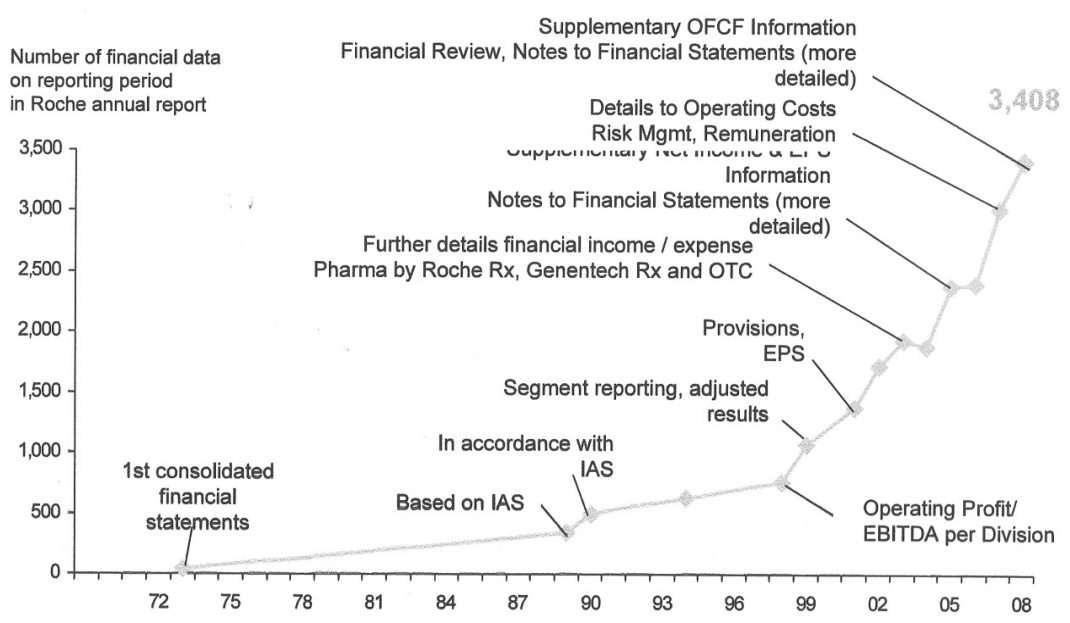

FIGURE 1.- The number of financial data points in the annual report of Roche Ltd. 1972-2008

significant implies that a significant fraction of firms overshoot their optimal disclosure level. Given the difficulty for managers to ex-ante assess the costs and benefits associated with different levels of disclosure, and given the strong general push towards more disclosure in recent decades, it does not seem entirely implausible that a certain percentage of firms should overproduce disclosure. To corroborate that disclosure, as measured in this paper, is related to the sheer amount of data points I collect annual reports for 2009 and code the number of pages in each firm's report (PAGES). Controlling for firm size and other firm characteristics I find, as expected, a positive and significant (at the 1\%-level) impact of DISCY on PAGES. Creating more direct measures of 'excessive' disclosure, and relating those measures to various outcome variables at the corporate level, is an interesting venue for future research. 


\section{Conclusions}

This paper empirically investigates whether the cost-of-capital hypothesis or optimal disclosure-hypothesis is more descriptive for the relationship between voluntary disclosure and firm value (measured as Tobin's Q). The cost-of-capital hypothesis suggests that increased disclosure leads to a higher firm value through a beneficial impact on the cost of capital. According to the standard arguments in the literature, this impact occurs because disclosure reduces information asymmetries between the firm and its investors, and between different categories of investors. The optimal disclosure-hypothesis acknowledges these benefits, but adds that costs related to disclosure imply the existence of an optimal level of disclosure, beyond which the net benefit of incremental disclosure turns negative.

In pursuing these hypotheses, this study benefits from access to a previously unexplored database on disclosure rankings for Swedish listed firms. Importantly, we can analyze the relationship between voluntary disclosure and firm value in a panel setting for three important categories of disclosure: annual reports, quarterly reports, and web-based reporting. While causality is difficult to infer, given the endogenous relation between disclosure and firm value, the evidence presented in this paper is consistent with the optimal disclosure hypothesis for disclosure in annual reports. The squared term of this disclosure measure is negative and statistically significant. I carry out a large set of robustness checks and find similar results. Once omitted variable bias is addressed, we find no association between disclosure in quarterly reports or web-based reporting on the one hand and Tobin's $\mathrm{Q}$ on the other.

Negative net benefits from additional disclosure (beyond a certain point) is more plausible in the context of annual reports, which during recent decades have seen a massive increase in the number of data items, and which are the targets in the current 'cut the clutter in financial reporting'-debate. While the results in this paper are a modest first step in determining the circumstances in which the optimal disclosure-hypothesis is descriptive, they do suggest that the winners in the analysts' rankings may not be the real beauties after all.

Accepted by: Prof. P. Theodossiou, Editor-in-Chief, June 2014 


\section{References}

Allayannis, G., and Weston, J.P. 2001. The use of foreign currency derivatives and firm market value. The Review of Financial Studies 14: 243-276.

Altman, E. I. 1968. Financial ratios, discriminant analysis and the prediction of corporate bankruptcy. Journal of Finance: 189-209.

Barry, C.B., and Brown, S.J. 1984. Differential information and the small firm effect. Journal of Financial Economics 13: 283-294.

Botosan, C.A. 1997. Disclosure level and the cost of equity capital. The Accounting Review 72: 323-349.

Botosan, C. 2006. Disclosure and cost of equity capital: What do we know? Accounting and Business Research, International Accounting Policy Forum: 31-40.

Botosan, C.A., and Plumlee, M.A. 2002. A Re-examination of disclosure level and the expected cost of equity capital. Journal of Accounting Research 40: 21-40.

Brown, S. 1979. The effect of estimation risk on capital market equilibrium. The Journal of Financial and Quantitative Analysis 14: 215-220.

Cheung, Y.L.; Jiang, P.; and Tan, W. 2010. A transparency disclosure index measuring disclosures: Chinese listed companies. Journal of Accounting and Public Policy 29: 259-280.

Daske, H., and Gebhardt, G. 2006. International financial reporting standards and experts' perceptions of disclosure quality. Abacus 42: 461-498.

Diamond, D.W., and Verrecchia, R.E. 1991. Disclosure, liquidity, and the cost of capital. The Journal of Finance 46: 1325-1359.

Easley, D., and O'Hara, M. 2004. Information and the cost of capital. The Journal of Finance 59: 1553-1583.

European Financial Reporting Advisory Group. 2012. Towards a disclosure framework for the notes. Discussion paper.

Francis, J.; Nanda, D.; and Olsson, P. 2008. Voluntary disclosure, earnings quality, and cost of capital. Journal of Accounting Research 46: 53-99.

Hail, L. 2002. The impact of voluntary corporate disclosures on the ex-ante cost of capital for Swiss firms. European Accounting Review 11: 741-773.

Hayes, R.M., and Lundholm, R. 1996. Segment reporting to the capital market in the presence of a competitor. Journal of Accounting Research 34: 261-279.

Healy, P.M.; Hutton, A.P.; and Palepu, K.G. 1999. Stock performance and intermediation changes surrounding sustained increases in disclosure. Contemporary Accounting Research 16: 485-520.

Healy, P., and Palepu, K. 2001. Information asymmetry, corporate disclosure and the capital markets: a review of the empirical disclosure literature. Journal of Accounting and Economics, 31: 405-440.

Jiao, Y. 2011. Corporate disclosure, market valuation, and firm performance. Financial Management 40: 647-676. 
Lambert, R.; Leuz, C.; and Verrecchia, R.E. 2007. Accounting information, disclosure, and the cost of capital. Journal of Accounting Research 45: 385-420.

Lang, M., and Lundholm, R. 1993. Cross-sectional determinants of analyst ratings of corporate disclosures. Journal of Accounting Research 31: 246-271.

Leuz, C., and Verrecchia, R.E. 2000. The economic consequences of increased disclosure. Journal of Accounting Research 38: 91-124.

Leuz, Z., and Wysocki, P. 2008. Economic consequences of financial reporting and disclosure regulation: A review and suggestions for future research. Working paper.

Marston, C.L., and Shrives, P.J. 1991. The use of disclosure indices in accounting research: A review article. The British Accounting Review 23: 195-210.

Morck, R.; Shleifer, A.; and Vishny, R.W. 1988. Management ownership and market valuation. An empirical analysis. Journal of Financial Economics 20: 293-315.

Nagar, V.; Nanda, D.; and Wysocki, P. 2003. Discretionary disclosure and stock-based incentives. Journal of Accounting and Economics 34: 283-309.

$\mathrm{Ng}$, J. 2011. The effect of information quality on liquidity risk. Journal of Accounting and Economics 52: 126-143.

Nikolaev, V., and Van Lent, L. 2005. The endogeneity bias in the relation between cost-of-debt capital and corporate disclosure policy. European Accounting Review 14: 677-724.

Oxelheim, L. 1999. Applying "MUST" analysis and the role of government in CI. Competitive Intelligence Review 10: 65-73.

Singhvi, S.S., and Desai, H.B. 1971. An empirical analysis of the quality of corporate financial disclosure. The Accounting Review 46: 129-138.

The Financial Reporting Council. 2011. Cutting clutter: Combating clutter in annual reports, Discussion paper.

Welker, M. 1995. Disclosure policy, information asymmetry, and liquidity in equity markets. Contemporary Accounting Research 11: 801-827. 